\title{
KERUSAKAN LINGKUNGAN AKIBAT AKTIVITAS MANUSIA PADA EKOSISTEM TERUMBU KARANG
}

\section{Netty Dahlah Uar', Sigit Heru Murti², dan Suwarno Hadisusanto ${ }^{3}$}

BAPPEDA Kabupaten Maluku Tenggara, Indonesia ${ }^{1}$, Fakultas Geografi ${ }^{2}$, Fakultas Biologi ${ }^{3}$, Universitas Gadjah Mada, Yogyakarta, Indonesia. nettydahlan@gmail.com

Diterima : Oktober 2014; Direvisi : Juni 2014; Dipubikasikan: Maret 2015

\begin{abstract}
ABSTRAK Terumbu karang merupakan ekosistem yang kompleks, khas, dan unik yang ditandai oleh tingginya keanekaragaman jenis biota penghuninya. Hubungan antar komponen biotik dan abiotik sangat erat, sehingga eksploitasi terhadap suatu jenis biota dapat mengakibatkan perubahan populasi biota lainya. Penyebab utama kerusakan ekosistem terumbu karang secara garis besar disebabkan oleh faktor alam dan faktor manusia. Kabupaten Maluku Tenggara memiliki sumberdaya pesisir dan laut yang menjadi unggulan, namun pada saat ini mulai mengalami kerusakan akibat aktifitas manusia yang kurang terkendali. Penelitian ini bertujuan untuk: (1) mengkaji kerusakan ekosistem terumbu karang di Pantai Ngurbloat Kecamatan Kei Kecil, Kabupaten Maluku Tenggara; (2) menganalisis faktor-faktor lingkungan yang mempengaruhi kerusakan ekosistem terumbu karang di daerah penelitian; dan (3) merumuskan kebijakan penanganan kerusakan eskositem terumbu karang di daereah penelitian. Metode yang digunakan dalam penelitian ini adalah metode survei. Analisis strategi pengelolaan lingkungan dapat disusun berdasarkan Keputusan Menteri Lingkungan Hidup No. 04 Tahun 2001 mengenai Kriteria Baku Kerusakan Terumbu Karang. Hasil penelitian menunjukkan kondisi terumbu karang berada pada kondisi sangat rusak (LP I), rusak (LPII) dan baik (LP III). Kerusakan tersebut diakibatkan karena antropogenik (kegiatan manusia) dan non-antropogenik (perubahan ekologis, faktor alam), antara lain: penangkapan ikan memakai bom ikan; panah; jaring; bubu; pengambilan karang untuk bahan bangunan dan hiasan akuarium; dan hiasan dinding. Rencana strategis pengelolaan terumbu karang di perairan Pantai Ngurbloat diusulkan sebagai berkut: (1) penetapan zonasi kawasan terumbu karang sesuai daya dukung lingkungan; (2) penetapan kegiatan atau usaha yang boleh atau tidak boleh dilakukan pada setiap zona yang telah ditetapkan; (3) pengendalian penangkapan ikan dengan alat tangkap yang ramah lingkungan (tidak merusak terumbu karang dan lingkungan) serta dilakukan pada lokasi dan musim (waktu) yang tepat; (4) meningkatkan kesadaran dan kepatuhan masyarakat nelayan di Pantai Ngurbloat akan pentingnya terumbu karang sebagai upaya optimalisasi pemanfaatan dan pelestarian sumberdaya alam.
\end{abstract}

Kata kunci: LIT; Pantai Ngurblot; strategi pengelolaan lingkungan; terumbu karang.

ABSTRACT Coral reefs are complex ecosystems, distinctive, unique, characterized by high diversity of biota inhabitants. Relation between biotic and abiotic components is very tightly, so that exploitation of a biota may result in changes to other biota populations. The main cause of coral reefs damagein outline caused by natural factors and human factors. Southeast Maluku District has a coastal and marine resources seeded, but at this time began to malfunction due to human activities that are less restrained. This study aims to: (1) assess the coral reef ecosystem damage in Ngurbloat Beach, Kei Kecil District, Southeast Maluku; (2) analyze the environment factors to affect the decline of coral reefs in the study area; and (3) formulate policies to handling of the coral reef ecosystem damage in study area. The method used in this study is survey method. Analysis of environmental management strategies can be organize based on the Decision of Environment Minister No. 04 Year 2001 about the criteria of coral reef damage standard. The results show condition of coral reefs in very damaged condition (LP I), broken (LPII) and good (LP III). The damage was caused by anthropogenic (human activities) and non-anthropogenic (changing of ecological, natural factors), among other things: fishing wear fish bombs; arrow; nets; bubu; taking of coral for building materials and aquarium ornament; and wall hangings. Strategic management plan of coral reefs Ngurbloat Beach is proposed as: (1) zoning of coral reefs area appropriate carrying capacity enviromental; (2) determination of activities or business may or may not do on any zones that have been set; (3) control of fishing with fishing gear that environmentally friendly (not damage coral reefs and the environment) as well as performed on location and season (time) right; (4) increasing public awareness and compliance in the fishermen of Ngurbloat Beach that importance of coral reefs as an effort to optimize the utilization and conservation of natural resources.

Key words: LIT; Ngurbloat Beach; environmental management strategies; coral reefs.

\section{PENDAHULUAN}

Terumbu karang merupakan sebuah ekosistem perairan yang dihuni oleh berbagai organisme yang berasosiasi dengan karang dan membentuk zat kapur (Whitten et al., 1987). Terumbu karang dibentuk oleh aktifitas hewan karang, yaitu simbiosis antara polip dengan alga Zooxanthellae, serta organisme penghasil kapur lainnya Terumbu karang merupakan ekosistem pesisir yang paling dominan di daerah tropis yang terletak di sepanjang garis pantai (Anderson, 1999). Salah satu penyusun ekosistem terumbu karang adalah karang yang termasuk anggota Subphyllum Cnidaria, 
kelas Anthozoa, ordo Scleractinia. Ekosistem terumbu karang terdapat di lingkungan perairan yang dangkal, seperti di paparan benua dan gugusan pulau-pulau di perairan tropis. Untuk mencapai pertumbuhan maksimum, terumbu karang memerlukan perairan yang jernih, dengan suhu perairan yang hangat, gerakan gelombang yang besar, dan sirkulasi air yang lancar serta terhindar dari proses sedimentasi (Dahuri dkk., 2001).

Terumbu karang memiliki berbagai peranan yang sangat penting dalam tatanan lingkungan kawasan pesisir dan lautan, baik ditinjau dari segi biologi dan ekologi maupun biotanya. Terumbu karang berfungsi sebagai gudang makanan yang produktif untuk perikanan, tempat pemijahan, bertelur, dan mencari makan berbagai biota laut yang bernilai ekonomis tinggi. Secara fisik, terumbu karang berfungsi sebagai pemecah ombak dan pelindung pantai dari sapuan badai, serta memiliki nilai estetika yang tinggi untuk pengembangan wisata bahari. Selain itu ekosistem terumbu karang merupakan salah satu sistem kehidupan yang majemuk dan khas daerah tropis yang mempunyai produktifitas dan keanekaragaman yang tinggi (Nybaken, 1988). Hubungan antar komponen biotik dan abiotik sangat erat, sehingga eksploitasi terhadap suatu jenis biota dapat mengakibatkan perubahan populasi biota lainnya.

Penyebab utama kerusakan ekosistem terumbu karang secara garis besar disebabkan oleh faktor alam dan faktor manusia. Kerusakan yang disebabkan oleh faktor alam misalnya: perubahan suhu air laut, topan, perubahan iklim global, gempa bumi, letusan gunung merapi, pemangsa dan penyakit. Dampak kerusakan ekosistem terumbu karang yang diakibatkan oleh faktor manusia lebih kronis dan tidak bersifat sementara. Kerusakan terumbu karang yang disebabkan oleh berbagai kegiatan manusia dapat secara langsung maupun tidak langsung. Contoh yang paling banyak antara lain adalah; kegiatan perikanan, usaha penangkapan ikan hias, ikan konsumsi, pengambilan kerang-kerang, dan udang dengan menggunakan bahan peledak, bahan kimia beracun, arus listrik, alat tangkap yang tidak ramah lingkungan seperti potasium, penangkapan yang berlebihan, serta pemanen yang tidak teratur. Aktivitas pencemaran lingkungan ini juga terjadi pada ekosistem terumbu karang di Kabupaten Maluku Tenggara.

Rusaknya terumbu karang pada kawasan Ohoi Ngurbloat akan mengancam kondisi sosial dan ekonomi bagi masyarakat yang ada di wilayah tersebut, khususnya nelayan tradisonal yang bergantung pada sumber daya terumbu karang. Berdasarkan latar belakang dan fakta lapangan yang telah diuraikan di atas, maka permasalahan yang dikaji dalam penelitian ini dirumuskan sebagai berikut ini: (1) bagaimanakah kerusakaan terumbu karang yang telah terjadi di Ohoi Ngurbloat Kecamatan Kei Kecil?; (2) Faktor-faktor lingkungan apa sajakah yang mempengaruhi kerusakan terumbu karang di daerah penelitian?; dan (3)bagaimanakah rumusan kebijakan untuk penanganan kerusakan terumbu karang di daerah penelitian?

\section{METODE PENELITIAN}

Metode penelitian yang digunakan dalam penelitian ini adalah metode survey. Penelitian ini dimulai dengan mengumpulkan data dan informasi serta mengklasifikasikannya menjadi data eksternal dan data internal. Pengumpulan data dilakukan untuk memperoleh informasi yang dibutuhkan dalam rangka mencapai tujuan penelitian. Data yang dikumpulkan pada titik sampel yang telah ditentukan sebelumnya (Gulö, 2002). Pengumpulan data dalam penelitian ini dilakukan pada masing-masing aspek dari variabel biofisik lingkungan dan variabel sosial.

Pengamatan lebih diarakan pada identifikasi tingkat kerusakan terumbu karang, jenis-jenis terumbu karang lebih banyak mengalami kerusakan, dan penyebab kerusakannya. Data dan parameter dalam penelitan ini adalah data primer dan data sekunder. Data primer berupa data persentase kerusakan terumbu karang pada Ohoi Ngurbloat yang diperoleh dengan cara melakukan survei lapang pada tahun 2014. Data sekunder mencakup data sebaran terumbu karang diperoleh melalui pengolahan Citra Landsat 7 ETM+ dan Landsat 5 TM. Pengolahan dilakukan dengan formula Lyzenga untuk membuat peta sebaran terumbu karang dengan bantuan pengolahan data sekunder yang terdiri dari data suhu, salinitas, kecerahan, arus, dan pasang surut.

Data terumbu karang dilakukan dengan menggunakan garis transek dengan cara memasang plot pada masing-masing lokasi pengamatan pada kedalaman 3 meter dan 10 meter. Disepanjang garis transek, penyelam melakukan pencatatan terhadap tutupan karang batu (hard coral), karang lunak (soft coral), pecahkan karang (rabble), alga, komponen abiotik dan fauna lain, serta komonitas ikan-ikan karang.

Penggunaan metode survei dalam menggambarkan kondisi terumbu karang disajikan dalam bentuk struktur komunitas yang terdiri dari data: persentase tutupan karang hidup, persentase tutupan karang mati, jumlah marga, jumlah jenis, jumlah koloni, ukuran koloni, kelimpahan, frekuensi kehadiran, bentuk 
pertumbuhan, indeks keanekaragaman jenis (Suharsono, 1996).

Metode yang digunakan untuk menggambarkan kondisi terumbu karang adalah metode Line Intercept Transect (LIT). Transek garis (Line Intercepts Transect/ LIT) digunakan pula untuk menilai, menaksir kerapatan/ keberadaan komunitas bentuk dari terumbu karang. Selain itu digunakan pula untuk memperkirakan luasan penutupan terumbu karang dalam sebuah stasiun sampling. Penggolongan/pengelompokan struktur komunitas karang dilakukan dengan menggunakan kategori bentuk tumbuh (lifeform) dengan melihat morfologi tutupan karang hidup, karang mati, bentuk substrat (pasir, lumpur), alga, dan keberadaan biota lain. Spesifikasi karang yang diharapkan dicatat adalah berupa bentuk tumbuh karang.

Penilaian kondisi ekosistem terumbu karang didasarkan pada 4 (empat) katagori menurut Gomez et al. (1981) yang disalin dalam lampiran 1 Keputusan Menteri Negara Lingkungan Hidup Nomor 04 Tahun 2001 tentang Kriteria Baku Kerusakan Terumbu Karang sebagaimana ditunjukkan pada Tabel 1.

\section{HASIL DAN PEMBAHASAN}

Kabupaten Maluku Tenggara terdiri atas satu gugusan kepulauan yaitu gugusan Kepulauan Kei yang terdiri atas Pulau Kei Kecil dengan luas seluruhnya 465,11 $\mathrm{Km}^{2}$ dan Pulau Kei Besar dengan luas 545,63 $\mathrm{Km}^{2}$. Secara astronomis Kecamatan Kei Kecil terletak antara $132^{\circ} 32^{\prime}-132^{\circ} 51^{\prime}$ Bujur Timur dan $05^{\circ} 32^{\prime}-05^{\circ} 48^{\prime}$ Lintang Selatan.

Hasil penerapan metode LIT untuk mengidentifikasi keanekaragaman jenis terumbu karang di daerah penelitian menunjukkan bahwa terumbu karang perairan Ohoi Ngilngof memiliki kekayaan taksa karang tertinggi, yaitu ditemukan 124 jenis (spesies) karang batu yang termasuk dalam 49 genera (marga) dan 16 famili (suku). Suku karang dengan jumlah spesies yang menonjol adalah Acroporidae (33 spesies) dan Faviidae (30 spesies), Poritidae (12 spesies) dan Fungiidae (11 spesies). Persen tutupan komponen biotik di dasar terumbu lebih tinggi $(69,42 \%)$ dari komponen abiotik $(33,58 \%)$ di perairan pesisir Ohoi Ngilngof dan khususnya pada pantai Ngurbloat dapat dilihat pada Tabel 2. Komponen biotik dengan nilai persen tutupan yang tinggi adalah karang batu (karang hidup). Karang batu bentuk tumbuh Non-Acropora memiliki kontribusi persen tutupan yang menonjol 40,84\%) terhadap persen tutupan karang batu dibanding karang batu bentuk tumbuh Acropora. Hasil inventarisasi menggunakan metode LIT pada seatiap statiun pengamatan disajikan pada Gambar 1. (Statiun Pengamatan I), Gambar 2. (Statiun Pengamatan II) dan Gambar 3. (Statiun Pengamatan III).

Hasil pengamatan menunjukkan bahwa sebagian besar kondisi terumbu karang di perairan sekitar Pantai Ngurbloat di Ohoi Ngilngof berada dalam keadaan rusak sampai dengan rusak berat, dengan persentase penutupan karang hidup berkisar antara 9,96 - 45,28 \%. Hanya satu dari tiga stasiun pengamatan yang termasuk dalam kategori, yaitu pada Stasiun Pengamatan III. Untuk dua lokasi yang lain masih dalam kondisi rusak dan rusak berat. Dari gambar 1-3 tersebut terlihat bahwa tutupan karang hidup tertinggi terdapat di Stasiun Pengamatan III. Rusaknya terumbu karang di Stasiun Pengamatan I dan II diduga karena adanya kegiatan yang merusak terumbu karang antara lain adanya penangkapan ikan secara tradisional yaitu dengan menggunakan bom, jaring, bubu, serta panah. Kerusakan pada kedua stasiun ini juga diakibatkan oleh pengaruh polusi berupa sedimen yang berasal dari bahan-bahan organik yang terbawa oleh arus akibat pengelohan budidaya mutiara karena di sekitar lokasi penelitian terdapat perusahan yang bergerak dalam budidaya mutiara.

Tabel 1. Kriteria Baku Kerusakan Terumbu Karang

\begin{tabular}{llc}
\hline Parameter & Kriteria Baku Kerusakan Terumbu Karang & Presentase Luas Tutupan Terumbu Karang Yang Hidup (Dalam \%) \\
\hline Rusak & Berat & $0-24,9$ \\
& Sedang & $25-49,9$ \\
Baik & Baik & $50-75,9$ \\
& Baik Sekali & $75-100$ \\
\hline
\end{tabular}

Sumber : Gomez et al.(1981)

Tabel 2. Kekayaan Spesies, Persen Tutupan Karang Batu dan Komponen Penyusun Terumbu Karang

\begin{tabular}{lllllllll}
\hline \multirow{2}{*}{ Lokasi Terumbu } & \multirow{2}{*}{ JumlahJenis } & \multicolumn{6}{c}{ Tutupan Komponen Penyusun Terumbu (\%) } & \multirow{2}{*}{ Kondisi } \\
& & Karang Batu & Acropora & Non Acropora & Fauna Lain & Algae & Komponen Abiotik \\
\hline Stasiun I & 43 & 30,9 & 14,9 & 16 & 21,18 & 0,4 & 47,52 & Rusak \\
Stasiun II & 41 & 22,72 & 2,76 & 19,96 & 4,58 & 2,62 & 69,42 & Sangat Rusak \\
Stasiun III & 74 & 66,96 & 23,9 & 43,06 & 4,26 & 0,98 & 27,64 & Baik \\
\hline
\end{tabular}




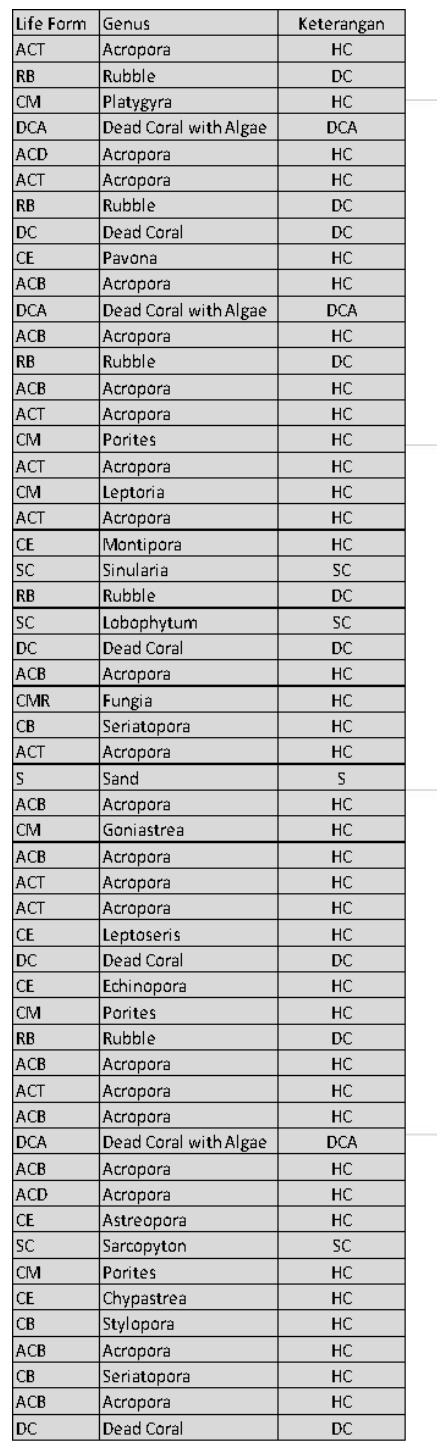

$-50$ $-30$ $-10$ 0

50 5 20 sen 2 20 $20^{\circ}$ 25 35

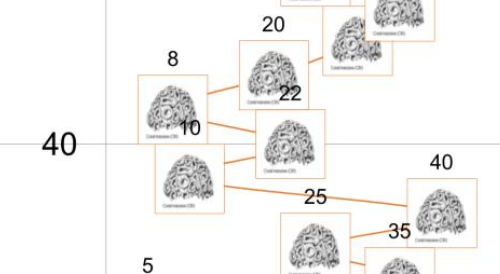

at $\frac{15}{\sqrt{2}-2}$

30

60

20

15

(sim)

6. 25

40

- 18 -

4

(62. 22

20

20

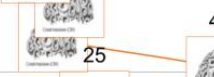

40

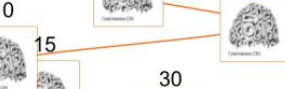

20

15. 35

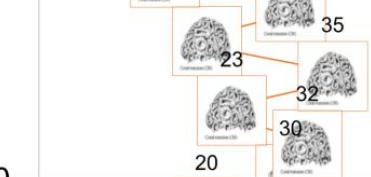

10

17

bes

13 .

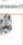

6is 28

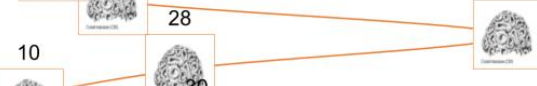

(2)
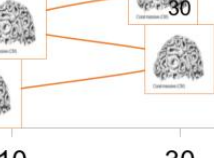

30

50

70

90

Gambar 1. Penerapan Metode Line Intercept Transect (LIT) di Stasiun Pengamatan 


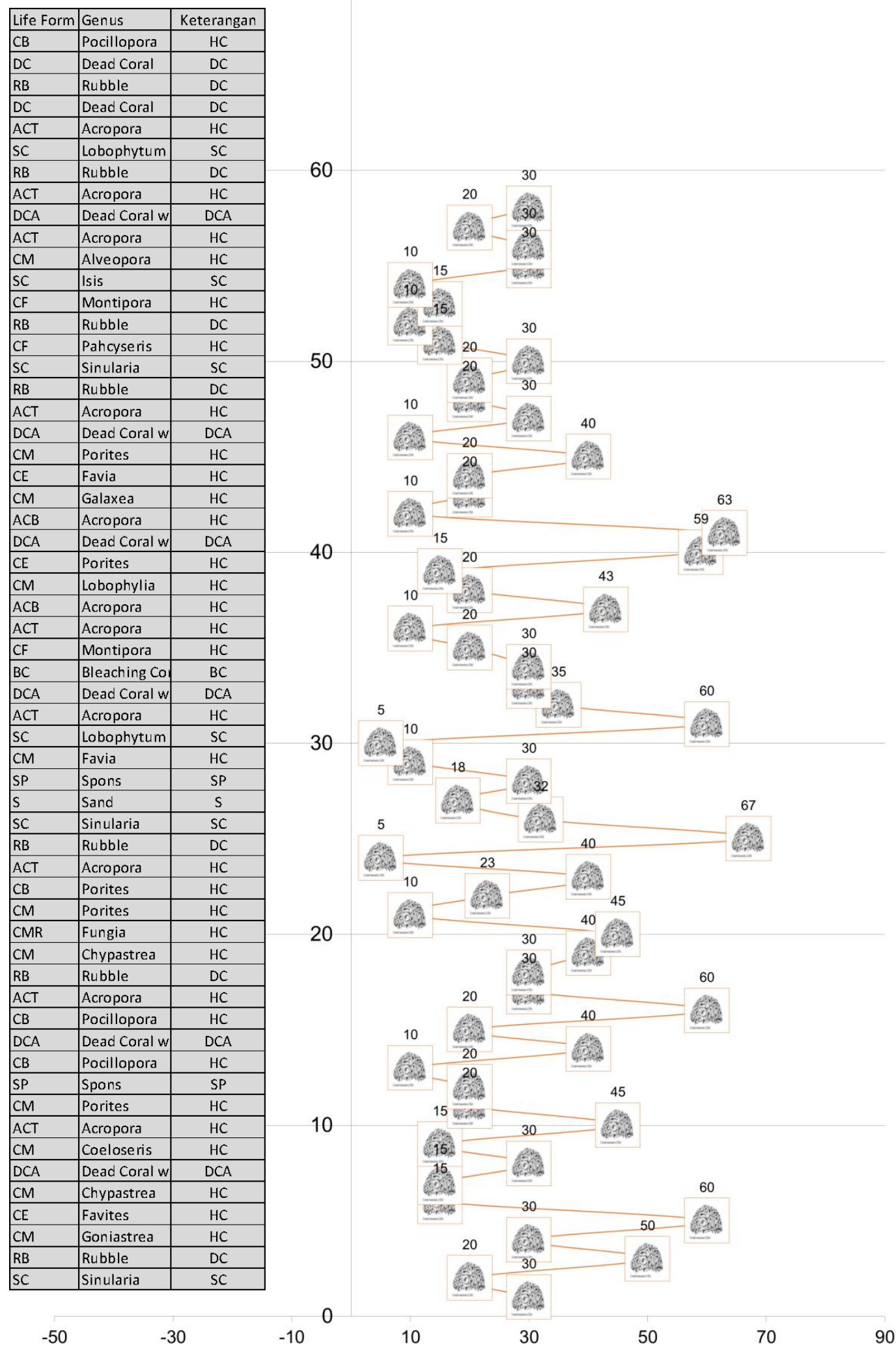

Gambar 2. Penerapan Metode Line Intercept Transect (LIT) di Stasiun Pengamatan II 


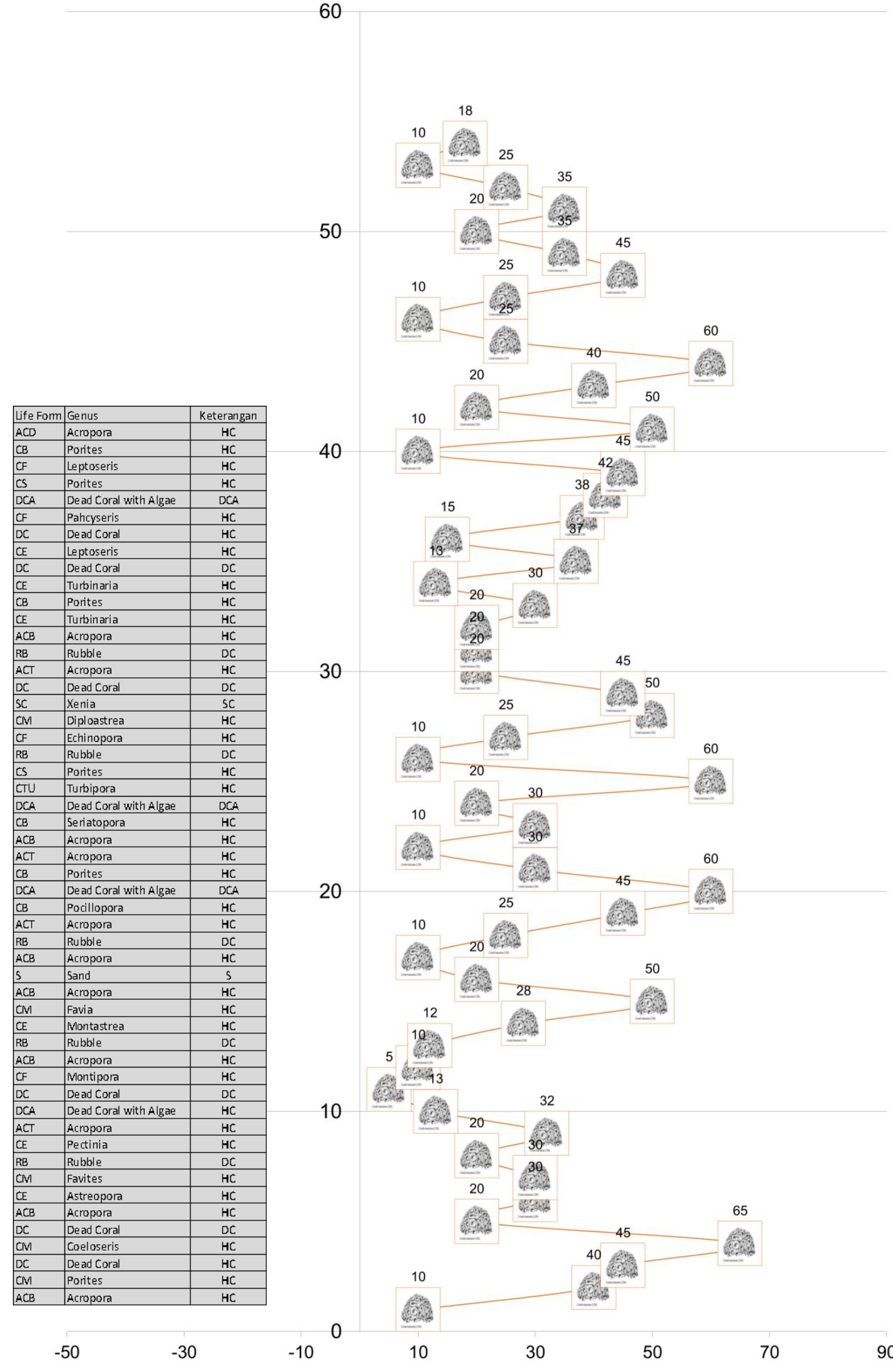

Gambar 3. Penerapan Metode Line Intercept Transect (LIT) di Stasiun Pengamatan III

Selain aktivitas manusia, kerusakan terumbu karang yang ditemukan di lokasi penilitian disebabkan pula oleh faktor alam yaitu adanya perubahan iklim sehingga menyebabkan terjadinya bleaching pada terumbu karang seperti pada Gambar 4A. yang diduga karena adanya faktor pemanasan global. Perubahan iklim yang terjadi di bumi bersumber dari kegiatan manusia yang mengabaikan lingkungan. Adanya perubahan iklim 
menyebabkan perubahan suhu panas air laut. Dengan kenaikan suhu tersebut, kehidupan terumbu karang yang semula terbiasa pada suhu konstan akan terancam rusak. Karang yang hidup bersimbiosis dengan sejenis alga zooxanthella akan keluar dari karang karena tidak tahan panas sehingga karang akan mati yang ditandai dengan perubahan wama putih seperti pada Gambar 4.

Berdasarkan hasil observasi terhadap kesadaran masyarakat terhadap kelestarian ekosistem terumbu karang belum baik. Masyarakat masih menggunakan karang sebagai bahan bangunan (pondasi) di lokasi penelitian. Hal ini harus menjadi bahan perhatian pemerintah untuk memberikan informasi dan dampak terhadap rusaknya ekosistem terumbu karang di masa depan baik secara ekonomi dan ekologi.

Permasalahan pengelolaan sumberdaya pesisir dan laut di Pantai Ngurbloat Ohoi Ngilngof tidak terlepas dari rendahnya pemahaman masyarakat tentang nilai dan manfaat sumberdaya alam berjangka panjang. Selama ini, pemahaman masyarakat terhadap nilai sumberdaya pesisir seperti perikanan, terumbu karang, dan sebagainya lebih kepada penilaian sumberdaya tersebut untuk pemanfaatan konsumsi langsung. Sedikit sekali masyarakat pesisir yang memahami pemanfaatan sumberdaya alam untuk kepentingan non-konsumtif seperti penahan

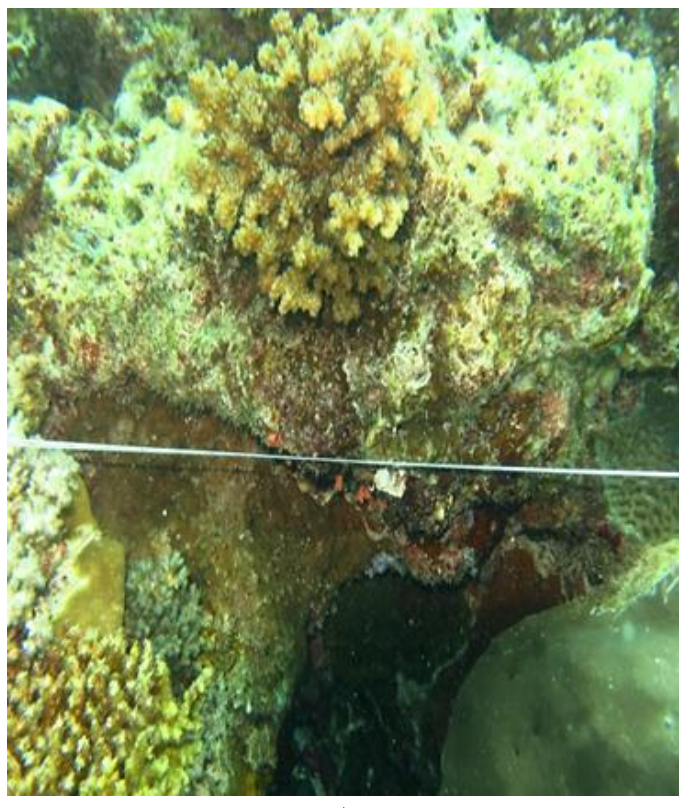

A abrasi, pengendali banjir, estetika, pemanfaatan untuk obat-obatan dan sebagainya yang terkadang nilai moneter non-konsumtifnya lebih besar dari nilai konsumtif.

Terhadap ketidaktahuan masyarakat yang terjadi ini dapat diartikan bahwa persepsi dan sikap keseluruhan masyarakat terhadap sumberdaya kelautan masih rendah. Secara umum dapat ditarik benang merah dari permasalahan ini adalah bahwa kerusakan lingkungan terumbu karang dan potensi sumberdaya pesisir dan laut lainnya di Pantai Ngurbloat Ohoi Ngilngof sebagaimana dideskripsikan sebelumnya lebih banyak disebabkan oleh faktor manusia yang dilatarbelakangi kemiskinan dan tingkat pendidikan yang rendah.

Berdasarkan hasil analisa seluruh hubungan kerusakan ekosistem terumbu karang dengan tingkat pendidikan, pekerjaan, dan penghasilan maka kondisi terumbu karang menurut persepsi masyarakat yang tinggal di lokasi penelitian termasuk dalam kategori rusak sedang dengan nilai persepsi tersebut maka perlu adanya pemecahan solusi permasalahan terkait pengelolaan lingkungan. Rencana pengelolaan terumbu karang di Pantai Ngurbloat Ohoi Ngilngof secara terpadu berdasar pertimbangan ekologis, teknis, dan sosial disajikan pada Tabel 3 .

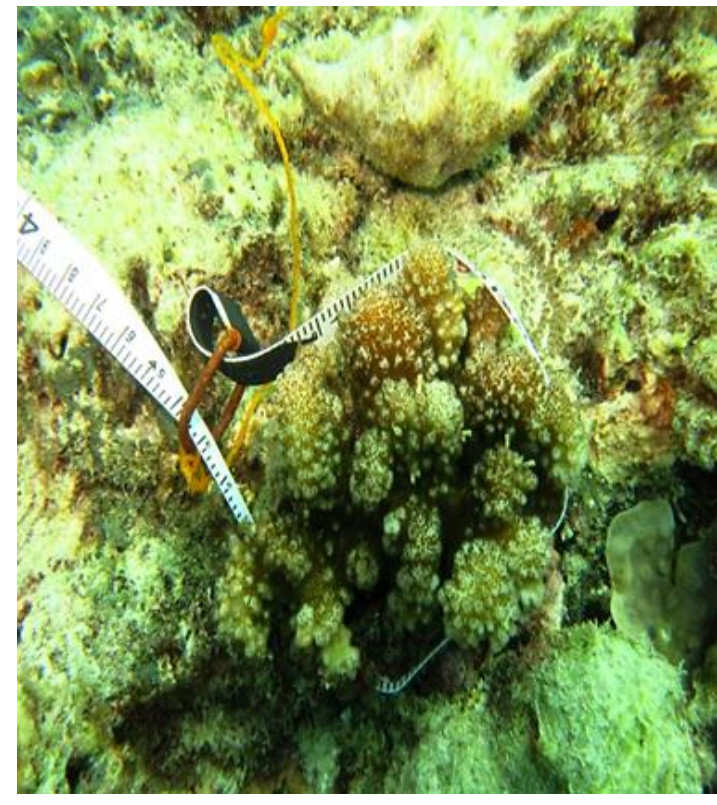

B

Gambar 4. Kondisi karang yang mengalami pemutihan (bleaching) yang teridentifikasi stasiun 1 akibat pemanasan global Sumber: Neles (2015) 
Tabel 3. Pembagian Zona Berdasarkan Potensi dan Permasalahan

\begin{tabular}{|c|c|c|c|c|}
\hline No & Pembagian Zona & Rekomendasi Kegiatan & Pengendalian Kegiatan & Keterangan \\
\hline 1 & Darat & $\begin{array}{l}\text { Penerapan ekonomi strategis } \\
\text { seperti pasar ikan dan } \\
\text { permukiman, dengan jarak } \\
\text { dari bibir pantai } 1 \mathrm{Km} \text {. }\end{array}$ & $\begin{array}{l}\text { Adanya penerapan teknologi } \\
\text { dan kontrol dari pemerintah }\end{array}$ & $\begin{array}{l}\text { Kelangsungan perekonomian } \\
\text { daerah dalam memanfaatkan } \\
\text { potensi sumberdaya alam }\end{array}$ \\
\hline 2 & Lamun & $\begin{array}{l}\text { Penerapan ekonomi strategis } \\
\text { seperti pasar ikan dan } \\
\text { permukiman, dengan jarak } \\
\text { dari bibir pantai } 500 \mathrm{~m}\end{array}$ & $\begin{array}{l}\text { Adanya penerapan teknologi } \\
\text { dan kontrol dari pemerintah }\end{array}$ & $\begin{array}{l}\text { Kelangsungan perekonomian } \\
\text { daerah dalam memanfaatkan } \\
\text { potensi sumberdaya alam }\end{array}$ \\
\hline 3 & Pasir & $\begin{array}{l}\text { Penerapan teknologi ramah } \\
\text { lingkungan dalam budidaya } \\
\text { ikan }\end{array}$ & $\begin{array}{l}\text { Adanya penerapan teknologi } \\
\text { dan kontrol dari pemerintah }\end{array}$ & $\begin{array}{l}\text { Kelangsungan perekonomian } \\
\text { daerah dalam memanfaatkan } \\
\text { potensi sumberdaya alam }\end{array}$ \\
\hline 4 & Terumbu karang & $\begin{array}{l}\text { Zona terlarang dalam } \\
\text { penangkapan ikan, akan } \\
\text { tetapi sebagai zona wisata } \\
\text { bahari }\end{array}$ & $\begin{array}{l}\text { Adanya promosi daerah } \\
\text { wisata bahari dengan pesona } \\
\text { terumbu karang di lokasi } \\
\text { penelitian }\end{array}$ & $\begin{array}{l}\text { Kelangsungan perekonomian } \\
\text { daerah dalam memanfaatkan } \\
\text { potensi sumberdaya alam } \\
\text { dalam menunjang ekologi dan } \\
\text { ekonomi balance di lokasi } \\
\text { penelitian }\end{array}$ \\
\hline
\end{tabular}

\section{KESIMPULAN}

1. Tingkat kerusakan lingkungan pada ekosistem terumbu karang di lokasi penelitian sebagian besar berada pada tingkat kerusakan berat.

2. Persepsi masyarakat tentang pentingnya pelestarian terumbu karang masih rendah, hal ini disebabkan oleh kegiatan eksploitasi terumbu karang untuk memenuhi kebutuhan ekonomi jangka pendek.

3. Rencana strategis pengelolaan terumbu karang di perairan Pantai Ngurbloat sebagai berkut:

(a) Penetapan zonasi kawasan terumbu karang sesuai daya dukung lingkungan.

(b) Penetapan kegiatan atau usaha yang boleh atau tidak boleh dilakukan pada setiap zona yang telah ditetapkan.

(c) Pengendalian penangkapan ikan dengan alat tangkap yang ramah lingkungan (tidak merusak terumbu karang dan lingkungan) dan dilakukan pada lokasi dan musim (waktu) yang tepat.

(d) Meningkatkan kesadaran dan kepatuhan masyarakat nelayan di Pantai Ngurbloat akan pentingnya terumbu karang sebagai upaya optimalisasi pernanfaatan pelestarian sumberdaya alam.

\section{DAFTAR PUSTAKA}

Anderson, D. T. (1999). Invertebate Zoology. New York: Oxford University Press.

Dahuri, Jakub Rais, Sapta Putra Ginting, Sitepu M.J. (2001). Pengelolaan Sumber Daya Wilayah Pesisir dan Lautan Secara Terpadu. Cetakan kedua, Jakarta: PT. Pradnya Paramita.

Gomez, E.D. and H.T. Yap. (1981). Monitoring Reef Condition. In: Coral Reef Management Handbook, R.A. Kenchingt6on and B.E.T. Hudson (Eds). Jakarta: Unesco Publisher.

Gulö, W. (2002). Metodologi Penelitian. Jakarta: PT. Gramedia Widiasarana Indonesia.

Nybaken. (1988). Biologi Laut Suatu Pendekatan Ekologis. Jakarta: Penerbit PT. Gramedia.

Suharsono. (1996). Jenis-jenis Karang yang Umum Dijumpai di Perairan Indonesia. Jakarta: Pusat Penelitian dan Pengembangan Oseanologi, Lembaga Ilmu Pengetahuan Indonesia,

Whitten, A. J., M. Mustafa., G. S. Hendarson. (1987). Ekologi Sulawesi. Alih Bahasa G. Tjitrosoepomo. Yogyakarta: Fakultas Biologi, Universitas Gadjah Mada. 